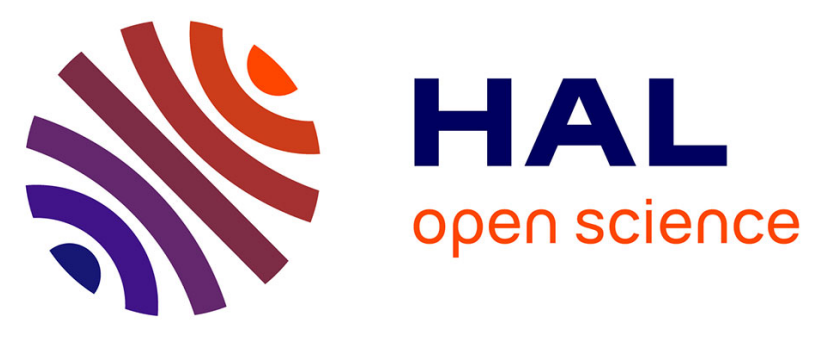

\title{
Short-time UVA exposure to human keratinocytes instigated polyunsaturated fatty acid without inducing lipid peroxidation
}

Kin Sum Leung, Hok Fung Chan, Ho Hang Leung, Jean-Marie Galano, Camille Oger, Thierry Durand, Jetty Chung-Yung Lee

\section{To cite this version:}

Kin Sum Leung, Hok Fung Chan, Ho Hang Leung, Jean-Marie Galano, Camille Oger, et al.. Shorttime UVA exposure to human keratinocytes instigated polyunsaturated fatty acid without inducing lipid peroxidation. Free Radical Research, 2017, 51 (3), pp.269-280. 10.1080/10715762.2017.1300885 . hal-02594151

\section{HAL Id: hal-02594151 \\ https://hal.science/hal-02594151}

Submitted on 15 May 2020

HAL is a multi-disciplinary open access archive for the deposit and dissemination of scientific research documents, whether they are published or not. The documents may come from teaching and research institutions in France or abroad, or from public or private research centers.
L'archive ouverte pluridisciplinaire HAL, est destinée au dépôt et à la diffusion de documents scientifiques de niveau recherche, publiés ou non, émanant des établissements d'enseignement et de recherche français ou étrangers, des laboratoires publics ou privés. 



\title{
Short-time UVA exposure to human keratinocytes instigated polyunsaturated fatty acid without inducing lipid peroxidation
}

\author{
Kin Sum Leung ${ }^{a}$, Hok Fung Chan ${ }^{a}$, Ho Hang Leung ${ }^{a}$, Jean-Marie Galano ${ }^{b}$, Camille Oger ${ }^{b}$, Thierry Durand ${ }^{b}$ \\ and Jetty Chung-Yung Lee ${ }^{a}$ (iD

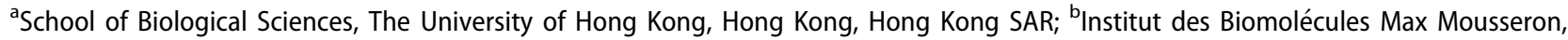 \\ UMR 5247 CNRS, ENSCM, Université de Montpellier, Montpellier, France
}

\begin{abstract}
Short-term exposure to ultraviolet A (UVA) radiation can directly injure our skin through inflammatory response and indirectly through oxidative stress, triggering polyunsaturated fatty acid (PUFA) peroxidation in skin cell membrane and formation of DNA adduct, 8-hydroxy-2'-deoxyguanosine $(8-\mathrm{OHdG})$. It is known that UVA exposure leads to photoaging, immunosuppression and skin cancer. However, the changes in PUFA and its oxidized metabolites, and cell cycle after short UVA exposure, are debatable. In this study, human keratinocytes (HaCaT) were exposed to low dose $\left(5 \mathrm{~J} / \mathrm{cm}^{2}\right)$ and high dose $\left(20 \mathrm{~J} / \mathrm{cm}^{2}\right)$ of UVA and assessed immediately, $8 \mathrm{~h}, 12 \mathrm{~h}$, and $24 \mathrm{~h}$ post-treatment. Both doses showed a transient suppression in S-phase after $8 \mathrm{~h}$ of UVA exposure, and $\mathrm{G}_{2} / \mathrm{M}$ phase arrest after 12-h UVA exposure in the cell cycle but subsequently returned to normal cycle. Also, no observable DNA damage took place, where 8-OHdG levels were below par after 24-h UVA exposure. A dose of $20 \mathrm{~J} / \mathrm{cm}^{2}$ UVA stimulated significant amount of arachidonic acid, n-3 docosapentaenoic acid, and docosahexaenoic acid (DHA) but lowered adrenic acid and eicospentaenoic acid after 24-h exposure. Among the 43 oxidized PUFA products determined, enzyme-dependent oxidized PUFAs, namely, 14-hydroxy-DHA (HDoHE) level reduced, and 8- and 13-HDoHE levels elevated significantly in a linear trend with post-treatment time. Out of the nonenzymatic oxidized PUFAs, a significant linear trend with post-treatment time was shown on the reduction of $5-\mathrm{F}_{2 \mathrm{t}}$-Isoprostane (IsoP), $15-\mathrm{F}_{2 \mathrm{t}}-\mathrm{IsoP}$, Isofurans, 5- $\mathrm{F}_{3 \mathrm{t}}-\mathrm{IsoP}$, Neurofurans, and $20-\mathrm{HDoHE}$. Our observations indicate oxidative stress through short UVA exposure on human keratinocytes did not have detrimental consequences.
\end{abstract}

\section{KEYWORDS}

Isoprostanes; $\mathrm{HaCaT}$; UVA; skin peroxidation;

polyunsaturated fatty acids

\section{Introduction}

Numerous epidemiologic evidences suggest ultraviolet radiation (UVR) is a major environmental cause of skin disorder. The key source of UVR is solar such as ultraviolet A (UVA, $320-400 \mathrm{~nm}$ ) which is the primary component to be in contact with human skin [1] and ultraviolet $B$ (UVB) which is the major contributor to sunburn. Both UVA and UVB can lead to a wide range of adverse effects $[2,3]$ such as photoaging, immunosuppression, and skin cancer [4-6], but the degree of damage by UVA is lesser than UVB. The risk concern of UVA is especially important in Asia compared to Europe due to higher level of UVA radiation exposure in winter season [7].

UVA activates reactive oxygen species (ROS) and in excess could overwhelm intra- and extracellular antioxidant defense mechanism, resulting in oxidative stress on the lipid raft, particularly polyunsaturated fatty acid
(PUFA) [8]. For example, UVA irradiation causes an inflammatory response in skin [9] and upregulates cyclooxygenase and lipoxygenase enzymes to release prostaglandin- $\mathrm{F}_{2 \alpha}\left(\mathrm{PGF}_{2 \alpha}\right)$ and 12-HETE from arachidonic acid (AA), respectively. The generation of these metabolites is found to be associated to immune responses, pigmentation, cutaneous wound healing and inflammatory diseases [10-13].

PUFA is prone to nonenzymatic oxidation by ROS and free radicals due to the vulnerable skipped diene double bonds in the structure, to produce oxidized lipid metabolites namely, isoprostanoids such as $F_{2}$-isoprostanes ( $F_{2}$-IsoPs) from AA. $F_{2}$-IsoPs is a well-validated biomarker for oxidative damage by free radicals and have shown to possess activities related to inflammation and immunity in different biological systems [9]. Furthermore, increased $\mathrm{F}_{2}$-IsoPs level is reported in sunburnt skin and wound fluid of damaged skin [14-17]. 
Aside from AA, other PUFAs exist such as docosahexaenoic (DHA) and eicosapentaenoic (EPA) acids that can be peroxidized to generate neuroprostanes (NeuroPs) and $F_{3}$-Isoprostanes $\left(F_{3}\right.$-IsoPs), respectively [18-20]. However, under high level of oxygen, the formation of isofuranoids, e.g. isofurans and neurofurans, dominates with minor amount of isoprostanoids. Nevertheless, consumption of DHA and EPA is suggested to contribute to healthy skin and prevent skin inflammation $[21,22]$, and more recently their oxidized metabolites are reported to protect cardiovascular system and have anti-inflammatory properties $[23,24]$.

UVA-induced oxidative damage may also occur at nuclear level, causing DNA damage. This results in the formation of numerous oxidative DNA adducts [25] specifically, 8-hydroxy-2'-deoxyguanosine (8-OHdG) which is the most abundant and widely studied due to its mutagenicity and utility as a reliable marker of oxidative DNA damage [5]. Oxidative DNA damage triggers cell cycle machinery to arrest its progression for cell repair [26]. If the DNA damage is beyond repair, it undergoes permanent cell cycle arrest or apoptosis to avoid mutation in the genome [27] and accordingly serve as the indicator of cell damage.

Although exposure to UVA is less detrimental to skin compared to UVB, several reports showed UVA could be harmful, leading to inflammation and lipid peroxidation. It is unclear if short daily UVA exposure to skin can trigger cell damage by free radical-oxidative stress, and if recovery is possible. In this study, human keratinocytes (HaCaT cells) were exposed to short-time UVA to investigate the etiology of the cell cycle and PUFA lipid profiles including its oxidized metabolites.

\section{Materials and methods}

\section{Cell culture}

Human keratinocytes (HaCaT) (gift from Professor GSW Tsao, Li Ka Shing Faculty of Medicine, The University of Hong Kong) were maintained in a monolayer culture at $5 \% \mathrm{CO}_{2}, 37^{\circ} \mathrm{C}$ in RPMI-1640 supplemented with fetal bovine serum (10\% FBS) and penicillin - streptomycin (5\%). The cells were sub-cultured every 3 days at a 1:3 split ratio, and the experiments were performed at approximately at $70 \%-80 \%$ confluence unless stated.

\section{UVA irradiation treatment}

The culture medium of $\mathrm{HaCaT}$ cells was replaced by a thin layer of phosphate-buffered saline (PBS). The cells were then exposed to of 5,10 , or $20 \mathrm{~J} / \mathrm{cm}^{2}$ (100 Watt, $365 \mathrm{~nm}$, high-intensity UV Lamp, UVP ${ }^{\circledR}$ Blak-Ray ${ }^{\circledR}$,
Upland, CA) UVA dose. The irradiated cells were immediately re-incubated into the new culture medium and samples were taken at various time points: immediately after treatment $(0 \mathrm{~h})$, and $8 \mathrm{~h}, 12 \mathrm{~h}, 24 \mathrm{~h}$ post-treatment and then harvested using trypsin-EDTA (Sigma, St. Louis, MO). Nonirradiated control cells were treated accordingly.

\section{MTT assay}

MTT assay was used to quantitatively determine the rate of cellular proliferation by Mosmann's method with slight modifications [28]. Briefly, the cells were seeded at $1.2 \times 10^{4}$ cells/well in 96 well-plates. Following UVA treatment, the cells were incubated at $37^{\circ} \mathrm{C}, 5 \% \mathrm{CO}_{2}$ for $24 \mathrm{~h}$ before the MTT test was performed. The culture medium was supplemented with $100 \mu \mathrm{l}$ of MTT reagent ( $c=800 \mu \mathrm{g} / \mathrm{ml}$ ) to each well and incubated for $4 \mathrm{~h}$ at $37^{\circ} \mathrm{C}$. Afterward, MTT solution was removed and $100 \mu \mathrm{l}$ of acidified isopropanol was added. The plates were left in the dark and shaken for $30 \mathrm{~min}$. Absorbance readings were performed at $595 \mathrm{~nm}$ with the reference of $750 \mathrm{~nm}$ using iMark microplate reader (Bio-Rad, Hercules, CA). Inhibition rate of cell proliferation was calculated by 1 (OD of treated cells/OD of controls) $\times 100 \%$.

\section{Cell cycle analysis}

After UVA treatment, $\mathrm{HaCaT}$ cells were harvested and fixed with $5 \mathrm{ml}$ of ice-cold $70 \%$ ethanol and $5 \mathrm{mM}$ butylated hydroxytoluene (BHT) and $5 \mathrm{mM}$ indomethacin to prevent lipid peroxidation. For cell cycle analysis, the cell samples were prepared by Leung et al. [29] method with slight modifications. The fixed cells were centrifuged at $800 \times g$ for $5 \mathrm{~min}$ at $4{ }^{\circ} \mathrm{C}$ and washed with PBS. Then, the cells were incubated with propidium iodide (PI) staining solution containing PI $(50 \mu \mathrm{g} / \mathrm{ml})$, RNase $(10 \mu \mathrm{g} / \mathrm{ml})$, Tris-base $(0.01 \mathrm{M}), \mathrm{NaCl}(10 \mathrm{mM})$, and Nonidet P-40 (0.1\%) (Sigma-Aldrich, St Louis, MO). The stained cells were incubated in the dark for $30 \mathrm{~min}$ at room temperature and thereafter, DNA content was determined by flow cytometry (Beckman Coulter, Brea, CA) and analyzed using FlowJo software (TreeStar, Ashland, OR).

\section{Extraction of polyunsaturated fatty acids and oxidized lipid products}

PUFA and oxidized lipid products were extracted from cell samples $\left(\sim 1 \times 10^{6}\right.$ cells in PBS with BHT and indomethacin) collected as described previously [29]. First, the cells were freeze-thawed and then homogenized in $10 \mathrm{ml}$ of Folch solution (chloroform/methanol 2:1 $\mathrm{v} / \mathrm{v}+0.05 \%$ BHT) using blade homogenizer ( $\mathrm{T} 25$, ULTRA-TURRAX, IKA, China). After centrifugation at 
$800 \times g$ for $10 \mathrm{~min}$ at $4{ }^{\circ} \mathrm{C}$, the lower organic phase was transferred to a glass vial and the solvent was evaporated under a stream of nitrogen gas. The dried extract was re-suspended in $1 \mathrm{M}$ potassium hydroxide in methanol $(1: 1)$. The samples were then hydrolyzed overnight, in dark and at room temperature $\left(25^{\circ} \mathrm{C}\right)$. After hydrolysis, the samples were cooled and neutralized by hydrochloric acid. Finally, formic acid ( $\mathrm{pH} 4.5)$ was added and mixed together with heavy labeled internal standards $4-(\mathrm{RS})-4-\mathrm{F}_{4 \mathrm{t}}-$ NeuroP- $\mathrm{d}_{4}$ and $10-\mathrm{F}_{4 \mathrm{t}}-$ NeuroP- $\mathrm{d}_{4}$ synthesized by Durand's group (IBMM, Montpellier, France), 5- $\mathrm{F}_{2 \mathrm{t}}-\mathrm{IsoP}_{-} \mathrm{d}_{4}, \quad 15-\mathrm{F}_{2 \mathrm{t}}-\mathrm{IsoP}_{-} \mathrm{d}_{4}, \quad \mathrm{PGF}_{2 \alpha}-\mathrm{d}_{4}, \quad$ 5(S)HETE- $d_{8}, 12(S)-H E T E-d_{8}, 15(S)-H E T E-d_{8}, 20-H E T E-d_{6}$, arachidonic acid- $d_{8}$, eicosapentaenoic acid- $d_{5}$, and docosahexaenoic acid- $d_{5}$ (Cayman Chemical, Ann Arbor, MI). The samples were then cleaned and extracted using anionic exchange solid-phase extraction columns (60 mg, Oasis MAX, Waters, Milford, MA) as described in our previous reports [29-31].

\section{Lipids and oxidized lipid products analysis by LC-MS/MS analysis}

The extracted PUFA and oxidized lipid products were analyzed following our previous studies with modifications [29-32]. Liquid chromatography tandem mass spectrometry system consisting of 1290 Infinity LC system (Agilent, Santa Clara, CA) with a $\mathrm{C}_{18}$ column $(2.6 \mu \mathrm{m}$ particle size, $150 \times 2.1 \mathrm{~mm}$, Phenomenex, Torrance, $\mathrm{CA}$ ) maintained at $30^{\circ} \mathrm{C}$ was used. The mobile phase consisted of $0.1 \%$ formic acid in water $(\mathrm{A})$ and $0.1 \%$ formic acid in acetonitrile (B). The flow rate was set to $200 \mu \mathrm{l} /$ $\mathrm{min}$, and the injection volume was $10 \mu \mathrm{l}$. The gradient was first maintained at $10 \% \mathrm{~B}$ from 0 to $1 \mathrm{~min}$, then a linear gradient from $10 \%$ B to $98 \%$ B for $7 \mathrm{~min}$, then $98 \%$ B was held for $4 \mathrm{~min}$ and finally linear gradient from $98 \%$ B to $10 \%$ B for $0.1 \mathrm{~min}$. Afterward, the column was re-equilibrated to initial condition. A QTrap 3200 triple quadrupole mass spectrometer (Sciex Applied Biosystems, Framingham, MA) coupled to the LC was operated at negative atmospheric pressure chemical ionization (APCl) mode. The spray voltage was set to $-4000 \mathrm{~V}$, and nitrogen gas was used as curtain gas. The scan mode was multiple reaction monitoring (MRM) and the MS/MS transition was monitored as shown in Supplementary information [29,31,33]. Quantitation of each analyte was determined by relating the peak area with its corresponding deuterated internal standard peak. For the analytes without their corresponding deuterated internal standards i.e. ALA, AdA, n-3 DPA, 8(S)-, 9(S)-, and 11(S)-HETE, 5-F 2t-IsoP, 8$\mathrm{F}_{2 \mathrm{t}}$-IsoP, Isofurans, 7- $\mathrm{F}_{2 \mathrm{t}}$-DihomolsoP, 17- $\mathrm{F}_{2 \mathrm{t}}$-DihomolsoP,

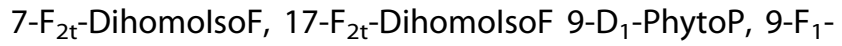

PhytoP, Ent-16- $\mathrm{F}_{1 \mathrm{t}}$-PhytoP, 9- $\mathrm{L}_{1}-\mathrm{PhytoP}$ 16-epi-16- $\mathrm{B}_{1}$ PhytoP, 16(R,S)-13-epi-ST- $\Delta^{14}-9-\mathrm{PhytoF}, 5-\mathrm{F}_{3 \mathrm{t}^{-}}-\mathrm{IsoP}, 8-\mathrm{F}_{3 \mathrm{t}^{-}}$ IsoP, 15- 3t $^{-}$-soP, 4-HDoHE, 7-HDoHE, 8-HDoHE, 10HDoHE, 11-HDoHE, 13-HDoHE, 14-HDoHE, 16-HDoHE, 17-HDoHE, 20-HDoHE, resolvin E1, resolvin D1, neurofurans, 4(RS)-ST- $\Delta^{5}-8-$ NeuroF, $14(R S)-14-\mathrm{F}_{3 \mathrm{t}}-\mathrm{IsoP}$, and 4$\mathrm{F}_{3 \mathrm{t}}$-IsoP, quantitation was performed by using the following deuterated internal standards, 5(S)-HETE- $d_{8}, 15-$ $\mathrm{F}_{2 \mathrm{t}}-\mathrm{IsoP}-\mathrm{d}_{4}$, and 4-(RS)-4- $\mathrm{F}_{4 \mathrm{t}}-\mathrm{NeuroP}-\mathrm{d}_{4}$. A total of 43 oxidized lipid products were quantitated in this study.

\section{Sample preparation for 8-OHdG analysis}

Measurement of 8-OHdG was made in the medium of the cell culture $\left(\sim 5 \times 10^{6}\right.$ cells $)$ after $24 \mathrm{~h}$ with and without UVA treatments since it can be metabolized and readily excreted as free by-product. Sample preparation was performed using Lee et al. [34] method with slight modifications. Briefly, the medium samples were thawed at room temperature and mixed thoroughly by vortex $(30 \mathrm{sec})$. After centrifugation at $5000 \times g$ for $5 \mathrm{~min}$ at $4{ }^{\circ} \mathrm{C}, 25 \mu \mathrm{l}$ of the sample medium was transferred into $2 \mathrm{ml}$ glass vials with inserts for LC-MS/MS measurement.

\section{LC-MS/MS analysis for 8-OHDG}

Levels of 8-OHdG were analyzed by Lee et al. [34] method with modifications. The 1290 Infinity LC system (Agilent, Santa Clara, CA) with a $\mathrm{C}_{18}$ column $(2.6 \mu \mathrm{m}$ particle size, $150 \times 2.1 \mathrm{~mm}$, Phenomenex, Torrance, $\mathrm{CA}$ ) was maintained at $30^{\circ} \mathrm{C}$. The mobile phase consisted of ammonium acetate $(10 \mathrm{mmol} / \mathrm{l}$, adjusted to $\mathrm{pH} 4.3$ with acetic acid) and acetonitrile (96.4:3.6 v/v). The flow rate was set to $500 \mu \mathrm{l} / \mathrm{min}$, and the injection volume was $10 \mu \mathrm{l}$. A QTrap 3200 triple quadrupole mass spectrometer (Sciex Applied Biosystems, Framingham, MA) was operated in a positive APCI mode. The spray voltage was set to $-4000 \mathrm{~V}$, and nitrogen gas was used as curtain gas. The scan mode was MRM, and the MS/MS transition (Supplementary information) was monitored by Lee et al. [34] method. To quantify the content of 8-OHdG, a series of calibrators was prepared (Supplementary information). The calibrators were prepared by spiking known amount of 8-OHdG standard into freeze-thawed cell free culture medium without any treatment.

\section{Statistical analysis}

Statistical analysis was performed using GraphPad Prism version 6.0 (GraphPad Prism, La Jolla, CA). All values were expressed as mean $\pm S D$. Data were analyzed by 2 way analysis of variance (ANOVA) including linear trend 
in post-treatment time, and $p<.05$ was noted as statistically significant.

\section{Results}

\section{Survival rate after exposure to physiological dose of UVA}

HaCaT cells were exposed to $5 \mathrm{~J} / \mathrm{cm}^{2}, 10 \mathrm{~J} / \mathrm{cm}^{2}$, and $20 \mathrm{~J} / \mathrm{cm}^{2}$ to test for a suitable low and high dose of UVA (Figure 1). The survival rate indicates the damage by physiological UVA dose to HaCaT cells was mild. Levels of $5 \mathrm{~J} / \mathrm{cm}^{2}$ and $10 \mathrm{~J} / \mathrm{cm}^{2}$ of UVA exposure reduced approximately $20 \%$ of the viable cells after treatment. On the other hand, doubling the dose $\left(20 \mathrm{~J} / \mathrm{cm}^{2}\right)$ reduced viable cells by $50 \%$ approximately. To investigate the severity of UVA on $\mathrm{HaCaT}$ cells, $5 \mathrm{~J} / \mathrm{cm}^{2}$ (equivalent to $15 \mathrm{~min}$ sunlight exposure) was chosen as low and $20 \mathrm{~J} / \mathrm{cm}^{2}$ (equivalent to $1 \mathrm{~h}$ sunlight exposure) as high physiological dose in our study.

\section{Effect of UVA irradiation on cell cycle}

No significant changes were observed in the cell cycle of viable $\mathrm{HaCaT}$ cells immediately after exposure of low $\left(5 \mathrm{~J} / \mathrm{cm}^{2}\right)$ and high $\left(20 \mathrm{~J} / \mathrm{cm}^{2}\right)$ UVA doses compared to control (Figure 2). The adverse effect on the cells was noticeable after $8 \mathrm{~h}$ for both UVA doses. A significant reduction of cells in S-phase compared to control was observed, showing that there is decreased DNA synthesis of the HaCaT cells after UVA treatment but this inhibition was only transient as we observed recovery after $12 \mathrm{~h}$ and $24 \mathrm{~h}$. However, the cell cycle of UVAtreated cells was not at homeostasis as $\mathrm{G}_{2} / \mathrm{M}$-phase arrest occurred after $12 \mathrm{~h}$ recovery for both UVA doses. The $\mathrm{G}_{2} / \mathrm{M}$ checkpoint potentially blocked the damaged cells to proceed to mitosis and was in transition from recovering by UVA damage [35]. However, after $24 \mathrm{~h}$ of

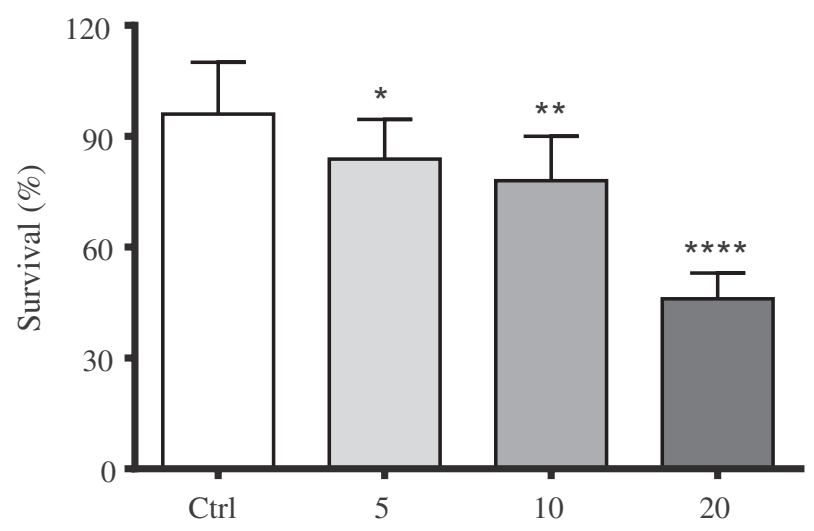

Figure 1. Cell viability of $\mathrm{HaCaT}$ cells exposed to different UVA treatment. Values are mean $\pm \mathrm{SD}, n=10,1.2 \times 10^{4}$ cells per set. ${ }^{*} p<.05,{ }^{* *} p<.01$, and ${ }^{* * * *} p<.0001$ versus control (Ctrl).
UVA exposure, the S-phase and $\mathrm{G}_{2} / \mathrm{M}$-phase were comparable to control but $G_{0} / G_{1}$-phase was significantly high compared to control for both doses. During this period, it appears the $\mathrm{HaCaT}$ cells could reinstate homeostasis and return to normal cell cycle.

\section{Effect of UVA irradiation on DNA damage}

Since there were increased $\mathrm{HaCaT}$ cells in $\mathrm{G}_{0} / \mathrm{G}_{1}$-phase after $24 \mathrm{~h}$ high-dose $\left(20 \mathrm{~J} / \mathrm{cm}^{2}\right)$ UVA exposure, we postulated that there may be DNA damage and potentially the release of the DNA adducts i.e. 8-OHdG into the cell medium. Since the excision, repair-damage and excretion process of the damaged DNA is long (usually 24-48 h in human urine), we measured the concentration in cell medium of HaCaT cells after $24 \mathrm{~h}$ from UVA exposure. Interestingly, no $8-\mathrm{OHdG}$ was detected in the treated $\mathrm{HaCaT}$ cell medium, indicating UVA doses used in this study was insufficient to cause major DNA damage in $\mathrm{HaCaT}$ cells.

\section{Effect of UVA irradiation on the lipid profile}

\section{Exposure of low dose}

Low $\left(5 \mathrm{~J} / \mathrm{cm}^{2}\right)$ UVA dose exposed to HaCaT cells showed no significant impact on the levels of $n-6$ PUFA, and all enzymatic and nonenzymatic oxidized PUFA products immediately after exposure $(0 \mathrm{~h})$. However, n-3 PUFAs were stimulated, as ALA levels were significantly elevated immediately after exposure compared to control (nontreated), and DHA levels were elevated at $8 \mathrm{~h}$ after exposure but returned to control level thereafter (Figure 3).

Treatment of $5 \mathrm{~J} / \mathrm{cm}^{2}$ UVA on HaCaT cells appeared to have a weak effect on the peroxidation of PUFA, and only 21 out of 43 oxidized PUFA products were detectable in the HaCaT cells and not all showed a significant change. Only some LOX-mediated oxidation of PUFA was activated after exposure, namely 8-HETE and 12-HETE levels from AA and 8-HDoHE from DHA were significantly increased whereas 7-HDoHE level decreased after $8 \mathrm{~h}$ compared to control. These changes were temporary and gradually returned to baseline level. We also observed in a linear manner a significant reduction of 14-HDoHE level and elevation of COX-mediated 13-HDoHE level with post-treatment time (Table 1).

Only a few nonenzymatic oxidized PUFA products were modified, mainly, 16-HDoHE level from DHA significantly increased after $8 \mathrm{~h}$, and 17-Dihomo-IsoP level from $\mathrm{AdA}$ and $15-\mathrm{F}_{3 \mathrm{t}}$-IsoP level from EPA increased significantly after $12 \mathrm{~h}$ exposure compared to control. 
However, all returned to control level at $24 \mathrm{~h}$, indicating the $\mathrm{HaCaT}$ cells could recover from oxidative stress after low-dose UVA exposure (Table 1, Figure 3). We further found a noticeable linear trend with post-treatment time on the suppression of $15-\mathrm{F}_{2 \mathrm{t}}$-IsoP from AA.

\section{Exposure of high dose}

High-dose $\left(20 \mathrm{~J} / \mathrm{cm}^{2}\right)$ UVA exposure to $\mathrm{HaCaT}$ cells showed no significant impact on the levels of PUFA, and enzymatic and nonenzymatic oxidized PUFA products immediately after exposure and after $8 \mathrm{~h}$ and $12 \mathrm{~h}$ (Figure 4). Only AA level decreased compared to controls after $8 \mathrm{~h}$ and $12 \mathrm{~h}$ of exposure (Figure 4, Table 2). However, after 24-h exposure, AA, n-3 DPA and DHA were significantly elevated whereas AdA and EPA decreased compared to control, and consistently, these findings showed a significant linear trend with posttreatment time (Figure 4).

As like low UVA dose exposure, only 21 out of 43 oxidized PUFA products were detected in the HaCaT cells after high-dose exposure. Mixed observations were made for the oxidized products of DHA mediated by enzymatic pathway after high UVA exposure.
Unlike other reports, products released via LOX such as resolvin D1 and its precursor 17-HDoHE were not detected [36]. However, 4-HDoHE and 14-HDoHE levels were reduced after $8 \mathrm{~h}$. Notably, 8-HDoHE level increased and 14-HDoHE level acutely reduced after $24 \mathrm{~h}$, and both showed significant decrease in linear trend with post-treatment time. Furthermore, only LOXmediated 12-HETE level from AA increased immediately after exposure but returned to control level (Table 2). Moreover, not all nonenzymatic oxidized PUFA products detected were significantly altered compared to control and only $5-\mathrm{F}_{3 \mathrm{t}}$-IsoP level from EPA was significantly lower compared to control at $12 \mathrm{~h}$ and $24 \mathrm{~h}$ posttreatment. Our observations also showed a significant linear trend with post-treatment time in $5-\mathrm{F}_{2 \mathrm{t}}-\mathrm{IsoP}$, Isofurans, $5-\mathrm{F}_{3 \mathrm{t}}-\mathrm{IsOP}$ and Neurofurans, and 20-HDoHE level reduction (Figure 4).

\section{Discussion}

UVA exposure to the skin can penetrate deep and be absorbed by the epidermis including the inner dermis whereas UVB is mainly absorbed by the stratum
0

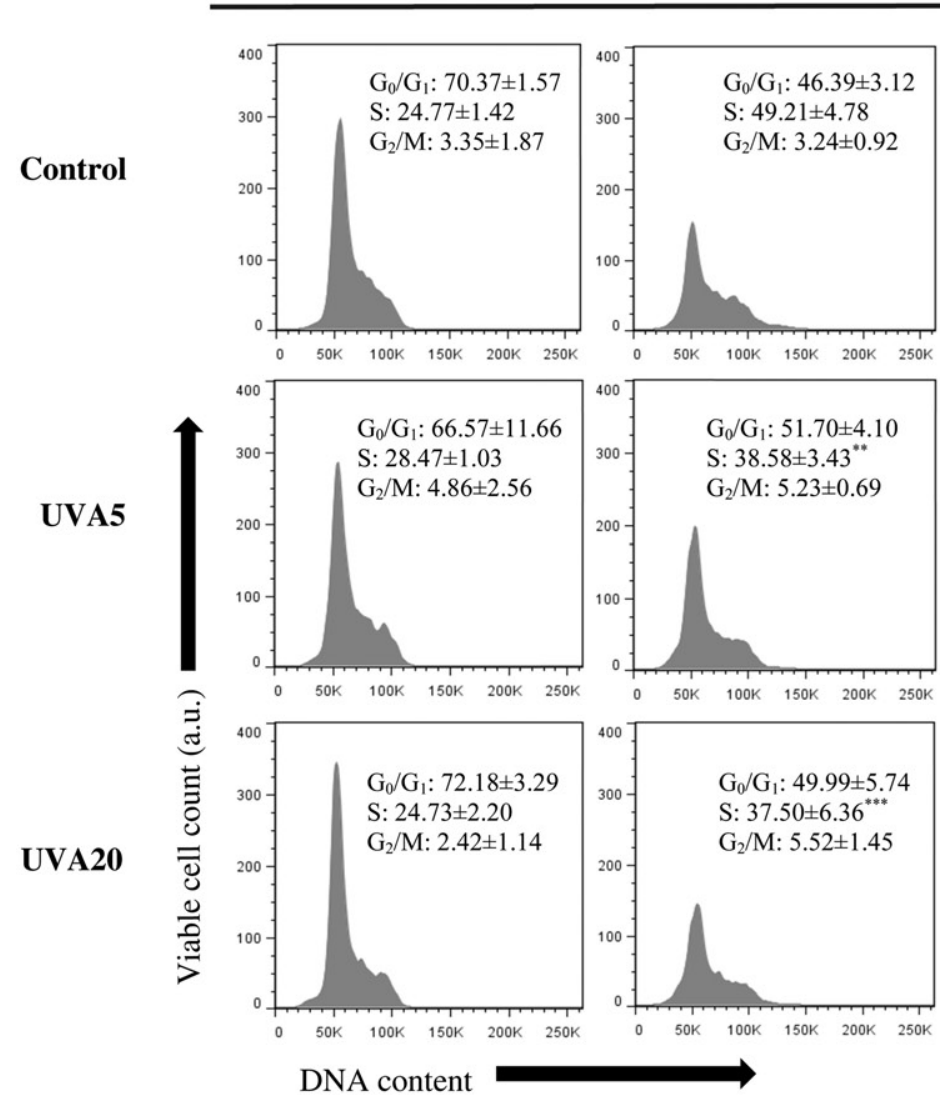

12
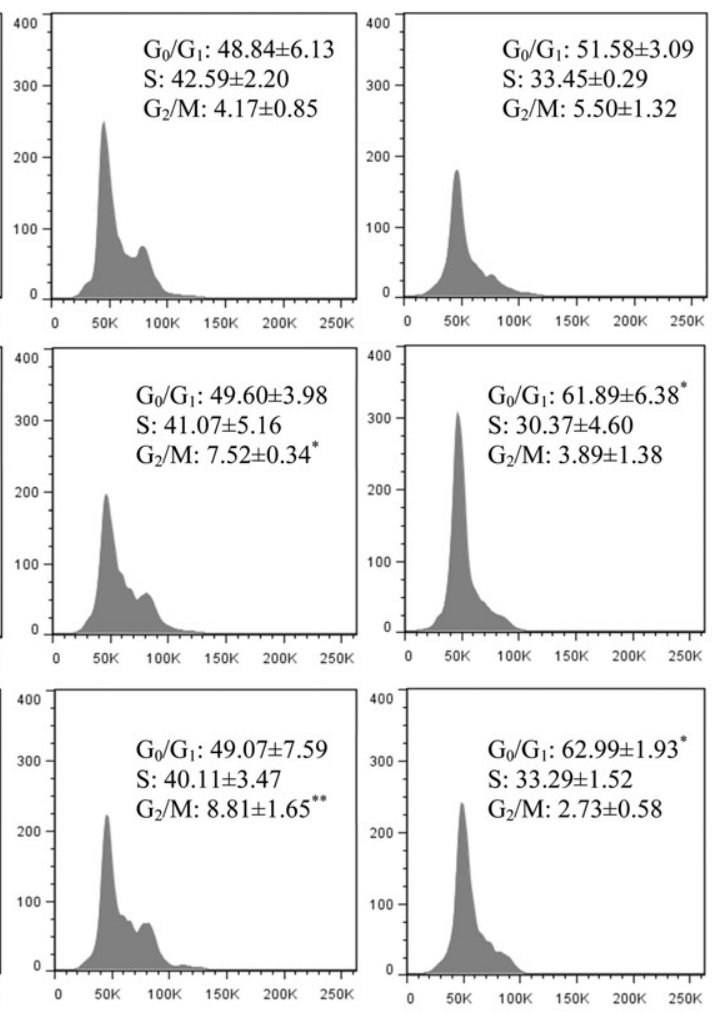

24

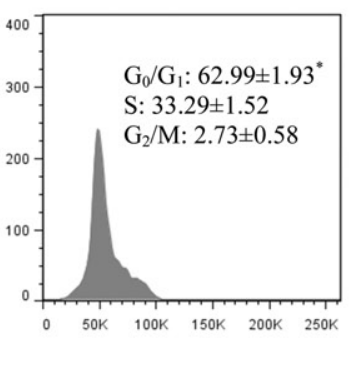

Figure 2. Cell cycle distribution of HaCaT cells before and after $5 \mathrm{~J} / \mathrm{cm}^{2}$ and $20 \mathrm{~J} / \mathrm{cm}^{2}$ UVA exposure. Values are mean $\pm S D, n=4$. ${ }^{*} p<.05,{ }^{*} p<.01$, and ${ }^{* * *} p<.001$ versus control. G0: Gap phase; G1: G1 checkpoint; S: synthesis phase; G2: G2 checkpoint; M: mitosis. 

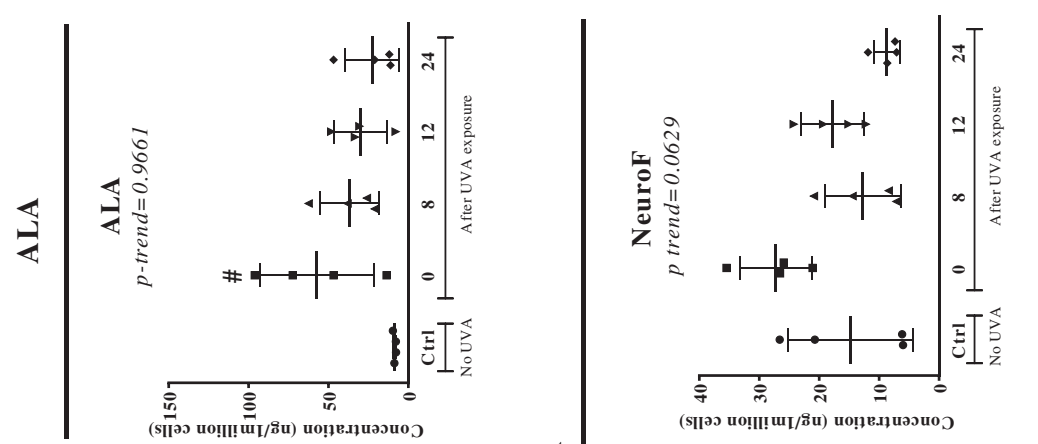

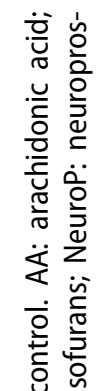

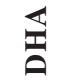
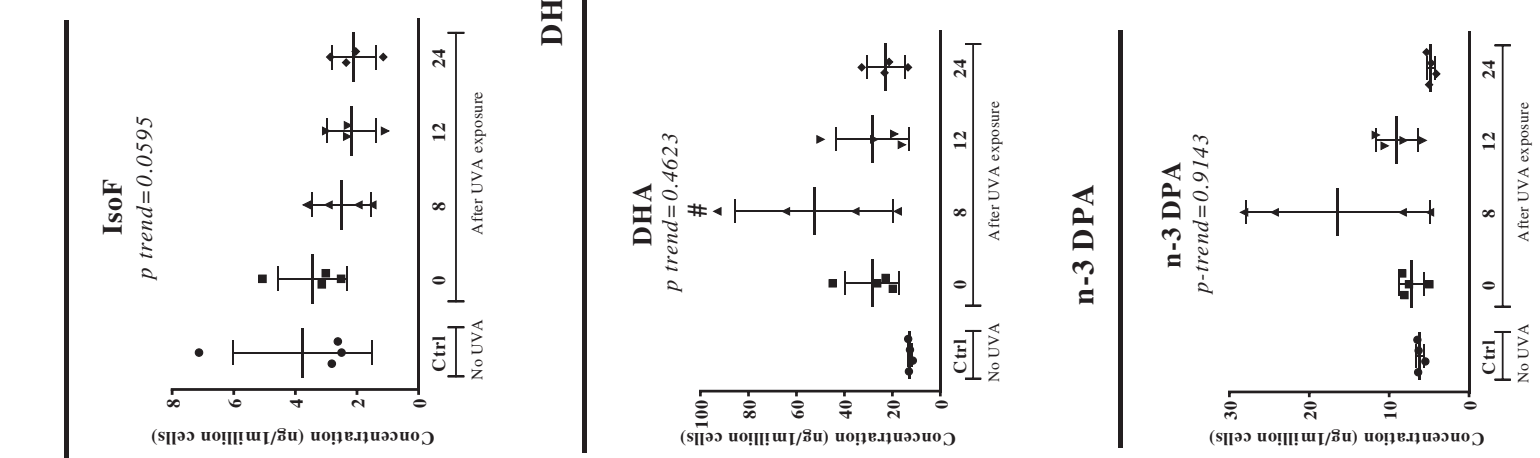

苛

$\stackrel{\bar{y}}{>}$
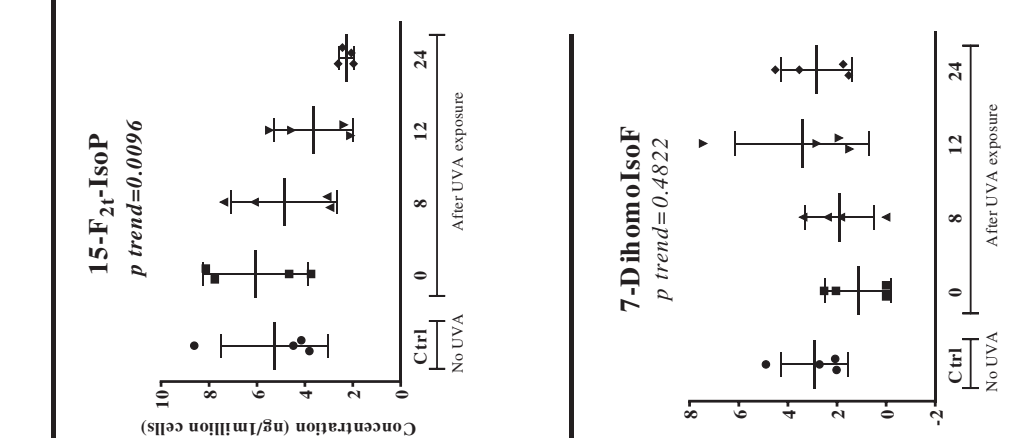

(a) $\frac{\breve{s}}{\frac{5}{5}}$

농

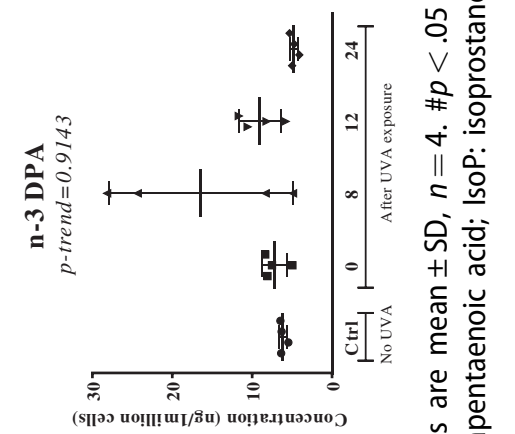

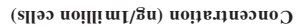
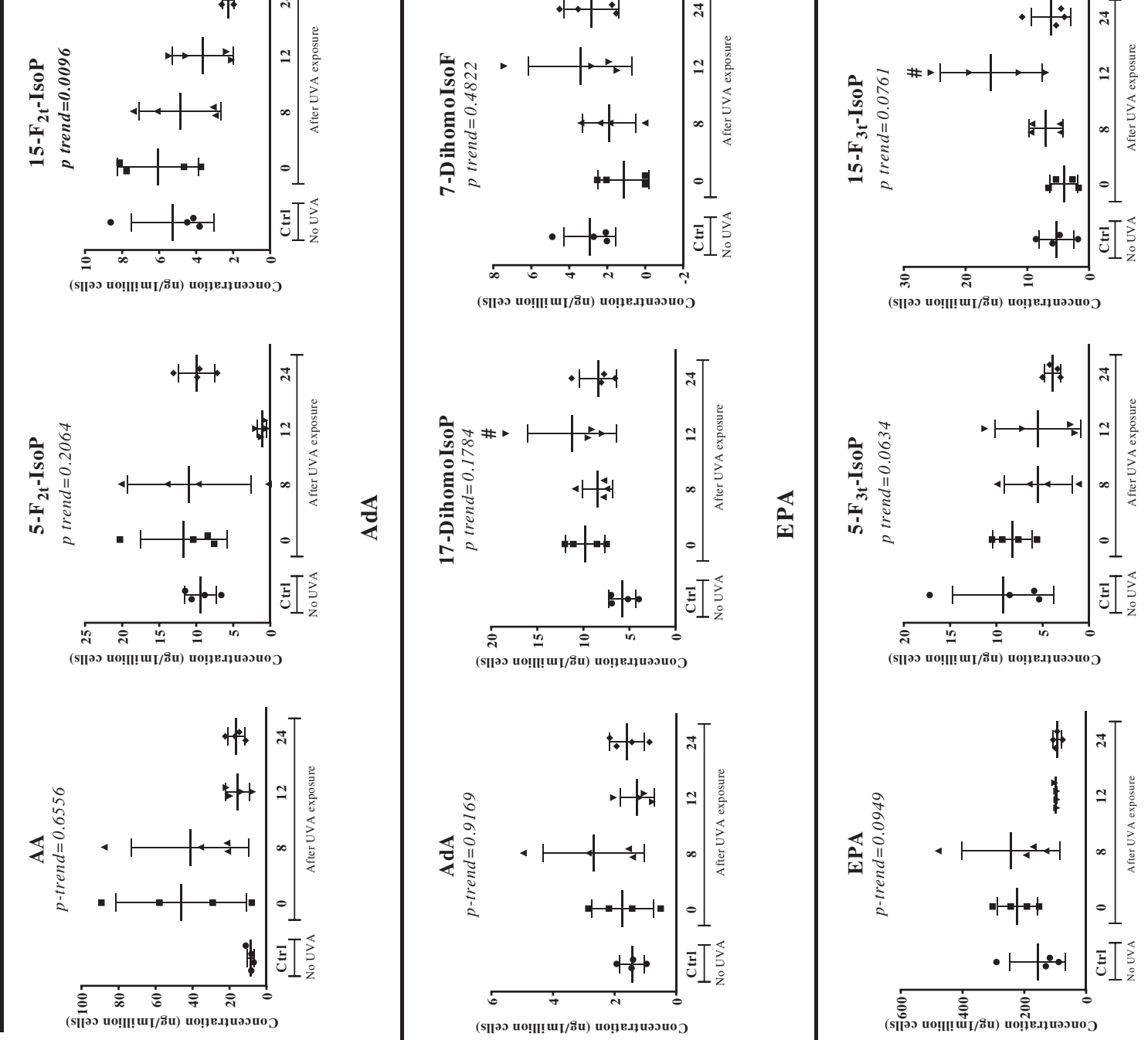

产芒

중

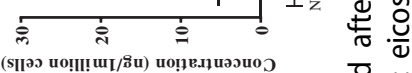

性

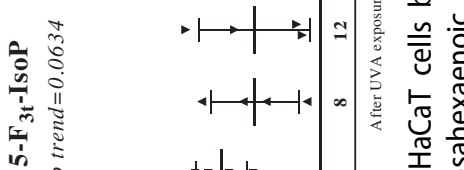

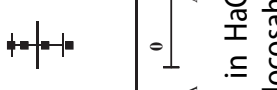

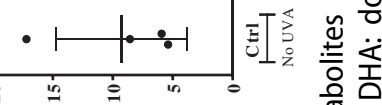

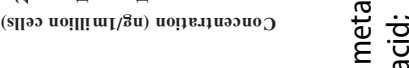

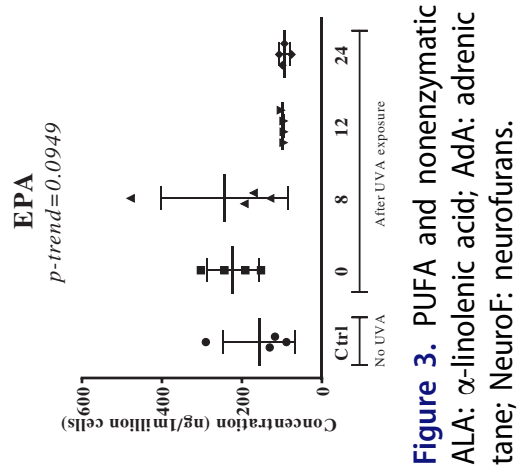


Table 1. Enzymatic and nonenzymatic metabolites in HaCaT cells before and after $5 \mathrm{~J} / \mathrm{cm}^{2}$ UVA exposure.

\begin{tabular}{|c|c|c|c|c|c|c|}
\hline & Control & $0 \mathrm{~h}$ & $8 \mathrm{~h}$ & $12 \mathrm{~h}$ & $24 \mathrm{~h}$ & $p$-trend \\
\hline \multicolumn{7}{|l|}{ cOX-mediated } \\
\hline $\mathrm{PGF}_{2 \alpha}$ & $1.48 \pm 0.39$ & $1.36 \pm 0.27$ & $1.19 \pm 0.32$ & $1.81 \pm 0.87$ & $1.30 \pm 0.43$ & 0.913 \\
\hline 13-HDoHE & $6.65 \pm 2.78$ & $2.43 \pm 0.34$ & $7.12 \pm 06.92$ & $18.35 \pm 6.85$ & $10.56 \pm 11.41$ & 0.047 \\
\hline \multicolumn{7}{|l|}{ LOX-mediated } \\
\hline 5-HETE & $1.65 \pm 0.80$ & $4.07 \pm 4.78$ & $6.25 \pm 3.91$ & $4.43 \pm 5.21$ & $11.83 \pm 12.75$ & 0.084 \\
\hline 8-HETE & $3.43 \pm 2.45$ & $4.14 \pm 0.06$ & $10.78 \pm 4.74^{*}$ & $6.73 \pm 3.36$ & $7.66 \pm 2.40$ & 0.087 \\
\hline 12-HETE & $0.88 \pm 0.20$ & $1.20 \pm 0.44$ & $2.52 \pm 1.62^{*}$ & $1.36 \pm 0.65$ & $0.60 \pm 0.15$ & 0.777 \\
\hline 4-HDoHE & $5.44 \pm 3.09$ & $4.43 \pm 1.92$ & $5.54 \pm 1.67$ & $4.73 \pm 2.78$ & $2.41 \pm 2.28$ & 0.192 \\
\hline 7-HDoHE & $20.47 \pm 4.88$ & $14.77 \pm 4.24$ & $13.12 \pm 2.67^{*}$ & $19.06 \pm 1.09$ & $15.56 \pm 1.49$ & 0.294 \\
\hline 8-HDoHE & $12.97 \pm 7.87$ & $13.13 \pm 6.89$ & $33.69 \pm 19.11^{*}$ & $16.03 \pm 7.24$ & $8.64 \pm 5.72$ & 0.732 \\
\hline 10-HDoHE & $4.94 \pm 2.58$ & $3.87 \pm 1.31$ & $5.37 \pm 0.29$ & $8.40 \pm 5.10$ & $2.75 \pm 1.86$ & 0.969 \\
\hline 11-HDoHE & $2.57 \pm 1.58$ & $3.31 \pm 1.94$ & $5.65 \pm 4.33$ & $9.01 \pm 7.47$ & $2.15 \pm 0.27$ & 0.480 \\
\hline 14-HDoHE & $38.04 \pm 22.15$ & $32.75 \pm 20.48$ & $24.73 \pm 9.90$ & $16.66 \pm 14.60$ & $17.96 \pm 4.19$ & 0.049 \\
\hline \multicolumn{7}{|l|}{ Nonenzymatic } \\
\hline 16-HDoHE & $7.86 \pm 5.32$ & $9.25 \pm 6.98$ & $26.55 \pm 12.32 *$ & $11.05 \pm 10.97$ & $5.06 \pm 5.27$ & 0.793 \\
\hline 20-HDoHE & $13.48 \pm 6.91$ & $9.65 \pm 4.04$ & $9.64 \pm 1.27$ & $10.09 \pm 2.66$ & $11.63 \pm 1.87$ & 0.620 \\
\hline
\end{tabular}

Values are mean $\pm S D, n=4$.

${ }^{*} p<.05$ versus control.

COX: cyclooxygenase; LOX: lipoxygenase; PGF $_{2 \alpha}$ : prostaglandin $\mathrm{F}_{2 \alpha ;}$ HDoHE: hydroxyl-DHA; HETE: hydroxyeicosatetraenoic acid.

corneum and some by the epidermis [37]. As a consequence, both radiation leads to skin photoaging and photocarcinogenesis via oxidative stress. UVB radiation is known to be more harmful on human skin than UVA as it has a higher ionization energy and easily absorbed by proteins and nucleic acids to cause direct DNA damage while UVA initiates injury from cells surface.

In this study, human keratinocytes (HaCaT cells) were exposed to $5 \mathrm{~J} / \mathrm{cm}^{2}$ and $20 \mathrm{~J} / \mathrm{cm}^{2}$ of UVA which is equivalent to $15 \mathrm{~min}$ and $1 \mathrm{~h}$ of sunlight exposure in cloudless sunny day, respectively [38]. This amount of sunlight exposure is common for indoor working people. Although Lowe et al. [39] showed UVA dose required to produce minimal erythema in normal fair skin is about $29 \mathrm{~J} / \mathrm{cm}^{2}$, which is equivalent to $1.5 \mathrm{~h}$ of sunlight exposure, a higher dose of UVA was not considered in our study as $20 \mathrm{~J} / \mathrm{cm}^{2}$ already reduced $50 \%$ of the $\mathrm{HaCaT}$ cell viability; a higher dose may further decrease the viable HaCaT cells, which is too low for us to regrow for analysis.

Despite the survival rate of $\mathrm{HaCaT}$ cells exposed to $20 \mathrm{~J} / \mathrm{cm}^{2}$ UVA to be $50 \%$ only, the cell cycle was not disrupted immediately. During the cell recovery period, transient S-phase reduction and $\mathrm{G}_{2} / \mathrm{M}$ phase arrest were observed but both returned to homeostasis after $24 \mathrm{~h}$. However, $G_{0} / G_{1}$-phase was still significantly high, demonstrating that the homeostasis of $\mathrm{HaCaT}$ cells from UVA exposure may be incomplete therefore, $8-\mathrm{OHdG}$ analysis was carried in the study to identify if potential DNA damage took place and excreted to the media. In correspondence, it is also suggested that elevated 8OHdG is associated to apoptosis [40]. We found 8-OHdG to be below the detection $(<0.1 \mathrm{nmol} / \mathrm{L})$ level when measured by LC-MS/MS indicating UVA exposure to $\mathrm{HaCaT}$ cells did not induce apoptosis and had the ability to recover to homeostasis. HaCaT cell is an immortalized human cell line containing mutant p53 gene at $\mathrm{H} 179 \mathrm{Y} / \mathrm{R} 282 \mathrm{~W}$. This mutation may cause changes in $\mathrm{HaCaT}$ cell compared to normal human keratinocytes which include modification in morphology, growth, and extended life span [41]. For this reason, $\mathrm{HaCaT}$ are susceptible to cell cycle alteration or DNA damage when exposed to UVA radiation compared to primary keratinocytes due to mutation therefore, the cell cycle analysis in this report may not align with those that use primary keratinocytes for experimentation.

Our study showed UVA equivalent to $15 \mathrm{~min}$ or $1 \mathrm{~h}$ sunlight exposure was sufficient to alter the composition of lipid profile in the skin cells. Of note, although we aspirated the necrotic cells suspended in the cell culture medium prior to lipid extraction in the study, it does not mean the composition of the cells used for the analysis were free of dead cells. It is known that skin has low PUFA content compared to other lipids [42] but can be the initiator and propagator of lipid peroxidation under UV exposure [43-45]. We identified that high dose of UVA radiations seems to accumulate PUFA and disrupt normal PUFA metabolism even after $24 \mathrm{~h}$. The accumulation of PUFA may alter the skin cells' function for example, increase the fluidity of cell membrane [45] and increase the ease of lipid peroxidation in skin [43-45] which may bring health risk to our skin. Indeed, we observed that high-dose UVA could stimulate $n-3$ DPA and DHA in HaCaT cells, and this group of $n-3$ PUFA especially DHA is known to have protective effect on skin-related ailments $[21,22]$.

We demonstrated that UVA exposure failed to extensively propagate the generation of nonenzymatic oxidized lipid products (IsoPs) from PUFA and more so, isofurans and neurofurans from $A A$ and 

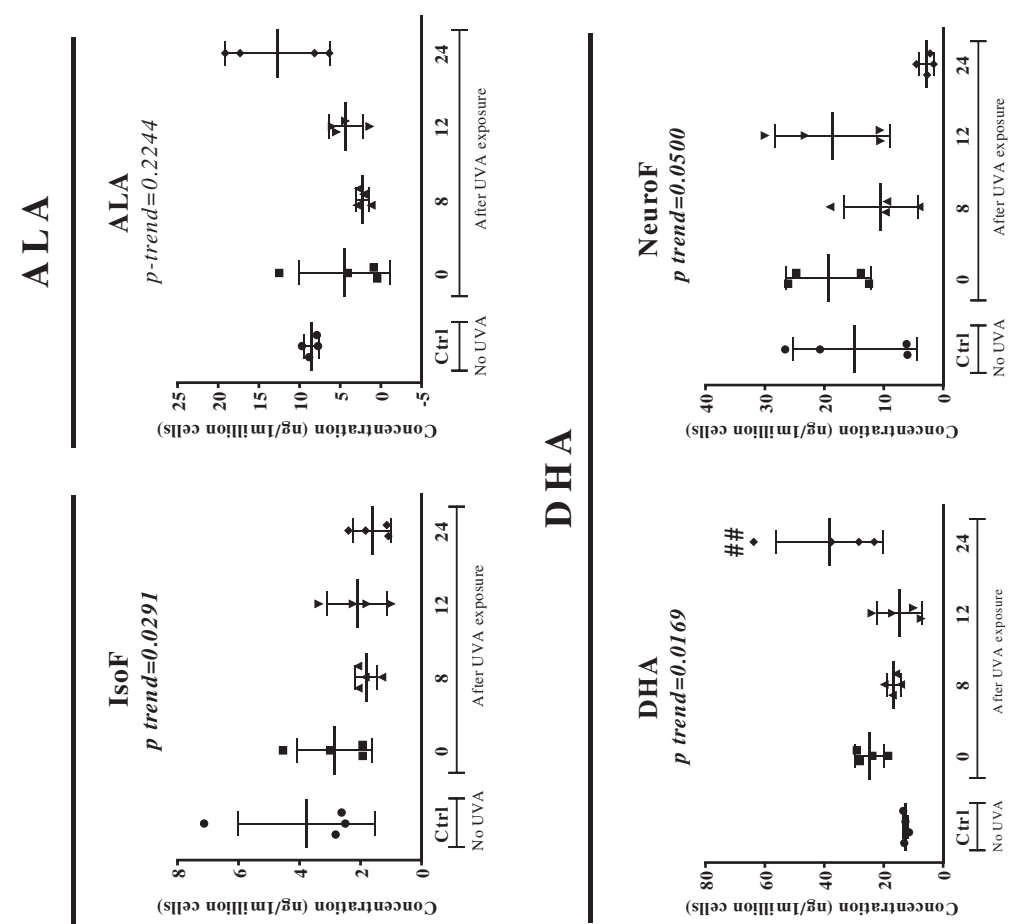

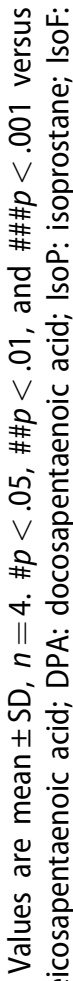
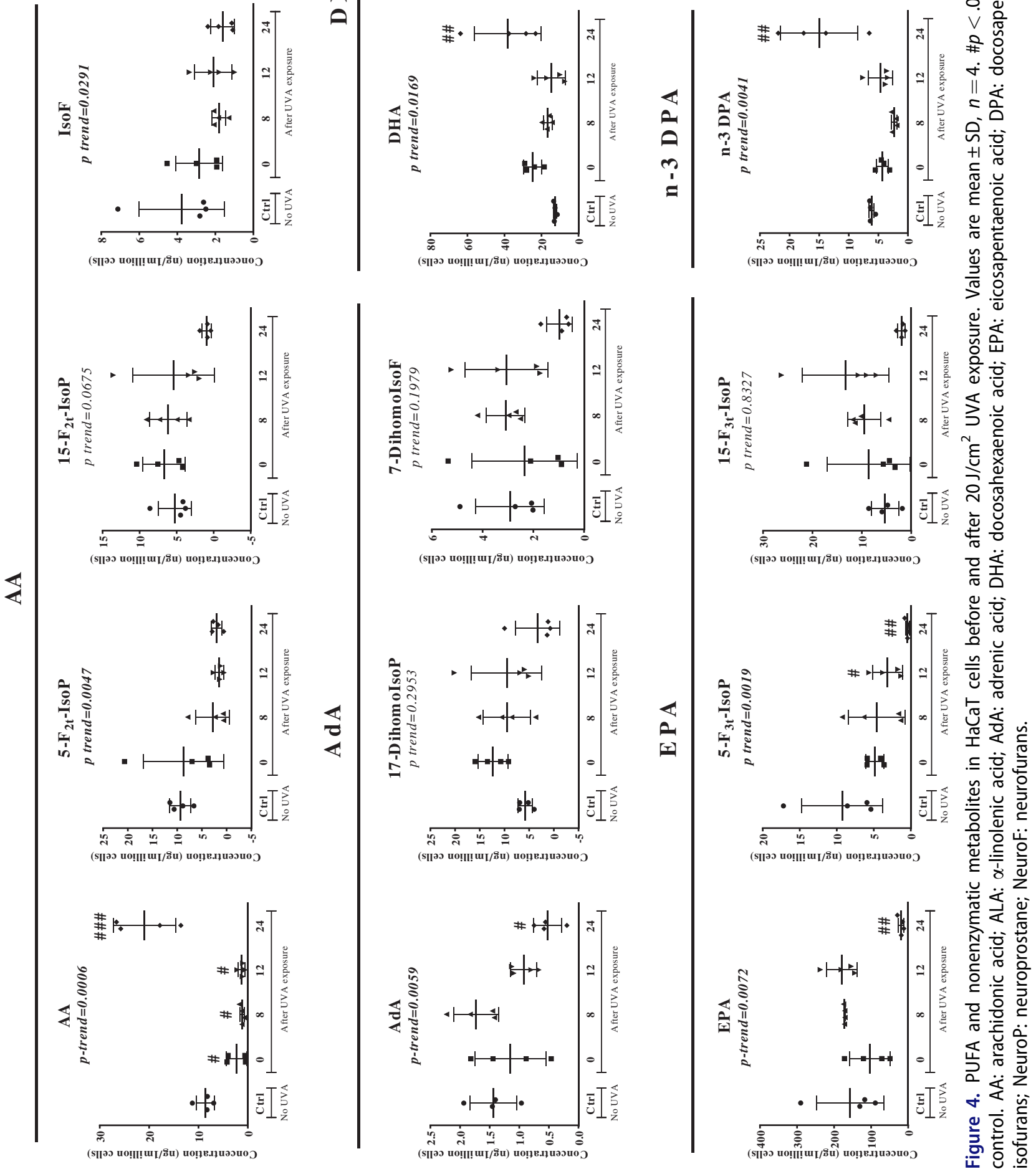
Table 2. Enzymatic and nonenzymatic metabolites in HaCaT cells before and after $20 \mathrm{~J} / \mathrm{cm}^{2}$ UVA exposure.

\begin{tabular}{|c|c|c|c|c|c|c|}
\hline & Control & $0 \mathrm{~h}$ & $8 \mathrm{~h}$ & $12 \mathrm{~h}$ & $24 \mathrm{~h}$ & $p$-trend \\
\hline \multicolumn{7}{|l|}{ COX-mediated } \\
\hline $\mathrm{PGF}_{2 \alpha}$ & $1.48 \pm 0.39$ & $6.02 \pm 3.34$ & $6.24 \pm 2.79$ & $4.62 \pm 2.35$ & $0.50 \pm 0.27$ & 0.3934 \\
\hline 13-HDoHE & $6.65 \pm 2.78$ & $12.56 \pm 11.61$ & $9.64 \pm 4.84$ & $9.14 \pm 3.96$ & $2.65 \pm 2.43$ & 0.3086 \\
\hline \multicolumn{7}{|l|}{ LOX-mediated } \\
\hline 5-HETE & $1.65 \pm 0.80$ & $14.40 \pm 17.12$ & $4.82 \pm 2.73$ & $10.63 \pm 6.27$ & $2.52 \pm 1.41$ & 0.8549 \\
\hline 8-HETE & $3.43 \pm 02.45$ & $20.57 \pm 17.14$ & $15.62 \pm 5.90$ & $9.19 \pm 6.71$ & $12.05 \pm 11.70$ & 0.7744 \\
\hline 12-HETE & $0.88 \pm 0.20$ & $3.34 \pm 3.58^{*}$ & $1.07 \pm 0.64$ & $0.98 \pm 0.35$ & $0.82 \pm 0.40$ & 0.2168 \\
\hline 4-HDoHE & $5.44 \pm 3.09$ & $3.05 \pm 31.86$ & $1.57 \pm 0.20^{*}$ & $4.26 \pm 2.15$ & $1.90 \pm 0.57$ & 0.0638 \\
\hline 7-HDoHE & $20.47 \pm 4.88$ & $44.54 \pm 29.14$ & $24.87 \pm 4.57$ & $26.78 \pm 4.80$ & $6.82 \pm 1.21$ & 0.1073 \\
\hline 8-HDoHE & $12.97 \pm 7.87$ & $12.06 \pm 6.05$ & $3.89 \pm 0.48$ & $7.10 \pm 3.52$ & $27.64 \pm 9.89^{*}$ & 0.0305 \\
\hline 10-HDoHE & $4.94 \pm 2.58$ & $6.72 \pm 3.22$ & $3.32 \pm 1.14$ & $3.41 \pm 0.70$ & $4.25 \pm 1.45$ & 0.1137 \\
\hline 11-HDoHE & $2.57 \pm 1.58$ & $1.75 \pm 9.79$ & $1.13 \pm 1.36$ & $1.77 \pm 1.05$ & $4.39 \pm 1.72$ & 0.0962 \\
\hline 14-HDoHE & $38.04 \pm 22.15$ & $15.69 \pm 9.55$ & $6.22 \pm 1.57^{* *}$ & $21.75 \pm 4.70$ & $1.01 \pm 0.33^{* *}$ & 0.0043 \\
\hline \multicolumn{7}{|l|}{ Nonenzymatic } \\
\hline 16-HDoHE & $7.86 \pm 5.32$ & $9.82 \pm 8.33$ & $6.76 \pm 1.56$ & $5.05 \pm 2.48$ & $6.08 \pm 2.32$ & 0.2012 \\
\hline 20-HDoHE & $13.48 \pm 6.91$ & $19.35 \pm 8.71$ & $8.97 \pm 2.89$ & $10.66 \pm 4.13$ & $2.53 \pm 1.62^{*}$ & 0.0007 \\
\hline
\end{tabular}

Values are mean $\pm S D, n=4$. Significant value is represented in bold font.

${ }^{*} p<.05, * * p<.01$ versus control.

COX: cyclooxygenase; LOX: lipoxygenase; $\mathrm{PGF}_{2 \alpha}$ : prostaglandin $\mathrm{F}_{2 \alpha i}$ HDoHE: hydroxy-DHA; HETE: hydroxyeicosatetraenoic acid.

$\mathrm{DHA}$, respectively. Moreover, there was a trend to find decreased isofurans and neurofurans after UVA treatment and the reason for this is unknown. Both metabolites are released in elevated oxygen tension and are highly associated with lung and neuronal damage under extreme oxygen condition. Although several studies reported the elevation of IsoPs in skin exposed to UVB [15,46-48], reports on UVA exposure are scarce. Insofar it is known that UVR can indirectly damage our skin via a high level of ROS [49] and lead to lipid peroxidation in cell membrane to release toxic (mainly from n-6 PUFA) and nontoxic (mainly from n-3 PUFA) products. The toxic ones tended to be lower and nontoxic ones higher after UVA exposure in this study. However, not all oxidized PUFA products were found in $\mathrm{HaCaT}$ in this study where only 21 out of the 43 products were observed. This may not be due to nonexistence of the other 22 products in the HaCaT cells, but rather, the concentration may be at trace level to be detected. Further, the elevation of IsoPs in skin is commonly found by UVB exposure but not UVA and may be due to higher ionization power by UVB than UVA; therefore, the level of ROS generated by the latter is lower. It agrees with Vostalova et al. [50] finding where dosedependent increase in myeloperoxidase activity, an inflammatory marker in the skin tissues of hairless mice, was observed only by UVB but not by UVA exposure. Eminently, studies showed PUFA converted to products such as $F_{2}$-IsoPs from AA in the skin after UVB exposure could lead to cell signaling disruption, carcinogenesis, and photoaging in skin [51]. However, the property of IsoPs production by UVA in skin is still unclear.

Generation of oxidized lipid products from enzymatic pathway is commonly associated to inflammation [52-54] and those related to AA are known to be pro-inflammatory and DHA to be anti-inflammatory [55]. For instance, it is reported cyclooxygenase (COX)dependent $\mathrm{PGF}_{2 \alpha}$ and lipoxygenase (LOX)-dependent 8-HETE from $A A$ to be pro-inflammatory agents $[52,56,57]$ in different tissues including skin. Our study did not display a strong pro-inflammatory effect via PGF $_{2 \alpha}$ and HETEs by UVA on HaCaT cells and instead, we found HDoHE from DHA to be activated. The role of HDoHE in keratinocytes is not well elucidated. Although no measurable amount of 17-DHoHE was found in our investigation, it is proposed to have putative antiinflammatory effect in epidermal of guinea pig supplemented with fish oil [58].

Alteration of PUFA observed in the study showed destabilization of PUFA metabolism especially $24 \mathrm{~h}$ after UVA exposure. AdA and EPA were suppressed compared to control whereas $A A, n-3 D P A$, and DHA were elevated after $24 \mathrm{~h}$ and these modifications were not associated with the changes of the oxidized lipid products. In addition, it appears no desaturation and elongation of $n-3$ DPA and DHA from EPA took place before $24 \mathrm{~h}$ but then reactivated after $24 \mathrm{~h}$, releasing more than control levels while simultaneously depleting EPA. This observation suggests exposure of $1 \mathrm{~h}$ UVA to the skin requires $24 \mathrm{~h}$ to return to PUFA homeostasis. Regardless, it is noted that some levels of PUFAs and oxidized lipid metabolites measured had a large deviation within the same set of sample treatments. This may be attributed by the rate of free radical generation and oxidation by UVA which could be less controllable compared to other extrinsic manipulation such as sonoporation as shown in our previous report [29].

In conclusion, short-term UVA exposure to $\mathrm{HaCaT}$ cells appears not as deleterious as anticipated. HaCaT cells may have a certain level of defense mechanism, 
e.g. elevation of DHA when exposed to UVA thereby assisting them to recover from potential damage. Nonetheless, in our study, UVA received from $1 \mathrm{~h}$ duration of sunlight exposure can modify PUFA composition and its metabolism in skin cells. However, the effect on extensive exposure requires elucidation as it may be detrimental and pose a risk to skin health [59].

\section{Acknowledgements}

We would like to thank Small Project Fund (grant No. 104003748) from The University of Hong Kong for the support of this work.

\section{Disclosure statement}

The authors report no conflicts of interest. The authors alone are responsible for the content and writing of the paper.

\section{Funding}

We would like to thank Small Project Fund [grant No. 104003748] from The University of Hong Kong for the support of this work.

\section{ORCID}

Jetty Chung-Yung Lee (iD http://orcid.org/0000-0002-81757069

\section{References}

1. Cortat B, Garcia CC, Quinet A, Schuch AP, de LimaBessa KM, Menck CF. The relative roles of DNA damage induced by UVA irradiation in human cells. Photochem Photobiol Sci 2013;12:1483-1495.

2. Hoffmann RT, Schmelz M. Time course of UVA- and UVB-induced inflammation and hyperalgesia in human skin. Eur J Pain 1999;3:131-139.

3. Wolber R, Schlenz K, Wakamatsu K, Smuda C, Nakanishi $Y$, Hearing VJ, Ito S. Pigmentation effects of solar-simulated radiation as compared with UVA and UVB radiation. Pigment Cell Melanoma Res 2008; 21:487-491.

4. Takeuchi $H$, Runger TM. Longwave UV light induces the aging-associated progerin. J Invest Dermatol 2013; 133:1857-1862.

5. Agar NS, Halliday GM, Barnetson RS, Ananthaswamy $\mathrm{HN}$, Wheeler M, Jones AM. The basal layer in human squamous tumors harbors more UVA than UVB fingerprint mutations: a role for UVA in human skin carcinogenesis. Proc Natl Acad Sci USA 2004;101:4954-4959.

6. Halliday GM, Byrne SN, Damian DL. Ultraviolet A radiation: its role in immunosuppression and carcinogenesis. Semin Cutan Med Surg 2011;30:214-221.
7. Sabziparvar AA, Shine KP, de Forster PM. A modelderived global climatology of UV irradiation at the earth's surface. Photochem Photobiol 1999;69:193-202.

8. Ou-Yang H, Stamatas G, Saliou C, Kollias N. A chemiluminescence study of UVA-induced oxidative stress in human skin in vivo. J Invest Dermatol 2004; 122:1020-1029.

9. Ichihashi $M$, Ueda $M$, Budiyanto $A$, Bito $T$, Oka $M$, Fukunaga $M$, et al. UV-induced skin damage. Toxicology 2003;189:21-39.

10. Basu S. Bioactive eicosanoids: role of prostaglandin $F(2 \alpha)$ and $F_{2}$-isoprostanes in inflammation and oxidative stress related pathology. Mol Cells 2010;30: 383-391.

11. Rhodes LE, Gledhill K, Masoodi M, Haylett AK, Brownrigg $M$, Thody $A J$, et al. The sunburn response in human skin is characterized by sequential eicosanoid profiles that may mediate its early and late phases. FASEB J 2009;23:3947-3956.

12. Sugimoto $M$, Arai I, Futaki N, Hashimoto $Y$, Honma $Y$, Nakaike S. Role of COX-1 and COX-2 on skin PGs biosynthesis by mechanical scratching in mice. Prostaglandins Leukot Essent Fatty Acids 2006;75:1-8.

13. Ruzicka T. The role of the epidermal 12-hydroxyeicosatetraenoic acid receptor in the skin. Eicosanoids 1992; 5:S63-S65.

14. Yeoh-Ellerton S, Stacey MC. Iron and 8-isoprostane levels in acute and chronic wounds. J Invest Dermatol 2003;121:918-925.

15. Grundmann JU, Wiswedel I, Hirsch D, Gollnick HP. Detection of monohydroxyeicosatetraenoic acids and F2-isoprostanes in microdialysis samples of human UVirradiated skin by gas chromatography-mass spectrometry. Skin Pharmacol Physiol 2004;17:37-41.

16. Volpe A, Biasi D, Caramaschi P, Mantovani W, Bambara LM, Canestrini S, et al. Levels of F2-isoprostanes in systemic sclerosis: correlation with clinical features. Rheumatology 2006;45:314-320.

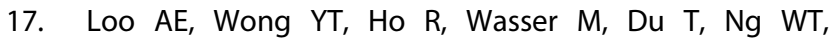
Halliwell B. Effects of hydrogen peroxide on wound healing in mice in relation to oxidative damage. PLoS One 2012;7:e49215.

18. Galano JM, Mas E, Barden A, Mori TA, Signorini C, De Felice $C$, et al. Isoprostanes and neuroprostanes: total synthesis, biological activity and biomarkers of oxidative stress in humans. Prostaglandins Other Lipid Mediat 2013;107:95-102.

19. Vigor C, Bertrand-Michel J, Pinot E, Oger C, Vercauteren J, Le Faouder $\mathrm{P}$, et al. Non-enzymatic lipid oxidation products in biological systems: assessment of the metabolites from polyunsaturated fatty acids. J Chromatogr B Analyt Technol Biomed Life Sci 2014; 964:65-78.

20. Song WL, Paschos G, Fries S, Reilly MP, Yu Y, Rokach J, et al. Novel eicosapentaenoic acid-derived F3-isoprostanes as biomarkers of lipid peroxidation. J Biol Chem 2009;284:23636-23643.

21. Storey A, McArdle F, Friedmann PS, Jackson MJ, Rhodes LE. Eicosapentaenoic acid and docosahexaenoic acid reduce UVB- and TNF-alpha-induced IL-8 secretion in keratinocytes and UVB-induced IL-8 in fibroblasts. J Invest Dermatol 2005;124:248-255. 
22. Puglia C, Tropea S, Rizza L, Santagati NA, Bonina F. In vitro percutaneous absorption studies and in vivo evaluation of anti-inflammatory activity of essential fatty acids (EFA) from fish oil extracts. Int J Pharm 2005;299:41-48.

23. Roy J, Le Guennec JY, Galano JM, Thireau J, BultelPonce $V$, Demion $M$, et al. Non-enzymatic cyclic oxygenated metabolites of omega-3 polyunsaturated fatty acid: bioactive drugs? Biochimie 2016;120:56-61.

24. Brooks JD, Musiek ES, Koestner TR, Stankowski JN, Howard JR, Brunoldi EM, et al. The fatty acid oxidation product 15-A3t-isoprostane is a potent inhibitor of NFkappaB transcription and macrophage transformation. J Neurochem 2011;119:604-616.

25. Lu AL, Li X, Gu Y, Wright PM, Chang DY. Repair of oxidative DNA damage: mechanisms and functions. Cell Biochem Biophys 2001;35:141-170.

26. Jean $C$, Hernandez-Pigeon $H$, Blanc $A$, Charveron $M$, Laurent $G$. Epidermal growth factor receptor pathway mitigates UVA-induced G2/M arrest in keratinocyte cells. J Invest Dermatol 2007;127:2418-2424.

27. Noonan FP, De Fabo EC. UVB and UVA initiate different pathways to p53-dependent apoptosis in melanocytes. J Invest Dermatol 2009;129:1608-1610.

28. Mosmann T. Rapid colorimetric assay for cellular growth and survival: application to proliferation and cytotoxicity assays. J Immunol Methods 1983;65:55-63.

29. Leung $\mathrm{KS}$, Chen $X$, Zhong $W$, Yu AC, Lee $C Y$. Microbubble-mediated sonoporation amplified lipid peroxidation of Jurkat cells. Chem Phys Lipids 2014; 180:53-60.

30. Lee $\mathrm{CY}$, Huang $\mathrm{SH}$, Jenner $\mathrm{AM}$, Halliwell B. Measurement of F2-isoprostanes, hydroxyeicosatetraenoic products, and oxysterols from a single plasma sample. Free Radic Biol Med 2008;44:1314-1322.

31. Chung ML, Lee KY, Lee CY. Profiling of oxidized lipid products of marine fish under acute oxidative stress. Food Chem Toxicol 2013;53:205-213.

32. Labuschagne CF, van den Broek NJ, Postma P, Berger $R$, Brenkman $A B$. A protocol for quantifying lipid peroxidation in cellular systems by F2-isoprostane analysis. PLoS One 2013;8:e80935.

33. Lee YY, Wong CK, Oger C, Durand T, Galano JM, Lee JC. Prenatal exposure to the contaminant perfluorooctane sulfonate elevates lipid peroxidation during mouse fetal development but not in the pregnant dam. Free Radic Res 2015;49:1015-1025.

34. Lee KF, Chung WY, Benzie IF. Urine 8-oxo-7,8-dihydro2'-deoxyguanosine (8-oxodG), a specific marker of oxidative stress, using direct, isocratic LC-MS/MS: method evaluation and application in study of biological variation in healthy adults. Clin Chim Acta 2010;411: 416-422.

35. Taylor WR, Stark GR. Regulation of the G2/M transition by p53. Oncogene 2001;20:1803-1815.

36. Serhan $\mathrm{CN}$, Petasis NA. Resolvins and protectins in inflammation resolution. Chem Rev 2011;111: 5922-5943.

37. Battie C, Jitsukawa S, Bernerd F, Del Bino S, Marionnet $C$, Verschoore $M$. New insights in photoaging, UVA induced damage and skin types. Exp Dermatol 2014; 23:7-12.
38. Valencia A, Kochevar IE. Ultraviolet A induces apoptosis via reactive oxygen species in a model for Smith-LemliOpitz syndrome. Free Radic Biol Med 2006;40:641-650.

39. Lowe NJ, Meyers DP, Wieder JM, Luftman D, Borget T, Lehman $M D$, et al. Low doses of repetitive ultraviolet $A$ induce morphologic changes in human skin. J Invest Dermatol 1995;105:739-743.

40. Xiao-Ying $Y$, Xiao-Wen $P$, Guo-Qiang $Z$, Jian-You G. Salidroside's protection against UVB-mediated oxidative damage and apoptosis is associated with the upregulation of Nrf2 expression. Photomed Laser Surg 2017;35:49-56.

41. Lehman TA, Modali R, Boukamp P, Stanek J, Bennett WP, Welsh JA, et al. p53 mutations in human immortalized epithelial cell lines. Carcinogenesis 1993;14: 833-839.

42. McCusker MM, Grant-Kels JM. Healing fats of the skin: the structural and immunologic roles of the omega- 6 and omega-3 fatty acids. Clin Dermatol 2010;28:440-451.

43. Hashimoto $M$, Shahdat $M H$, Shimada $T$, Yamasaki $H$, Fujii $Y$, Ishibashi $Y$, Shido O. Relationship between agerelated increases in rat liver lipid peroxidation and bile canalicular plasma membrane fluidity. Exp Gerontol 2001;37:89-97.

44. Day CA, Kenworthy AK. Tracking microdomain dynamics in cell membranes. Biochim Biophys Acta 2009; 1788:245-253.

45. Wiktorowska-Owczarek A, Berezinska M, Nowak JZ. PUFAs: structures, metabolism and functions. Adv Clin Exp Med 2015;24:931-941.

46. Schneider LA, Bloch W, Kopp K, Hainzl A, Rettberg P, Wlaschek $M$, et al. 8-Isoprostane is a dose-related biomarker for photo-oxidative ultraviolet (UV) B damage in vivo: a pilot study with personal UV dosimetry. $\mathrm{Br} \mathrm{J}$ Dermatol 2006;154:1147-1154.

47. Wiswedel I, Grundmann JU, Boschmann M, Krautheim A, Bockelmann R, Peter DS, et al. Effects of UVB irradiation and diclofenac on F2-isoprostane/prostaglandin concentrations in keratinocytes and microdialysates of human skin. J Invest Dermatol 2007;127:1794-1797.

48. Sirerol JA, Feddi $F$, Mena $S$, Rodriguez ML, Sirera $P$, Aupi $M$, et al. Topical treatment with pterostilbene, a natural phytoalexin, effectively protects hairless mice against UVB radiation-induced skin damage and carcinogenesis. Free Radic Biol Med 2015;85:1-11.

49. Sander CS, Chang H, Hamm F, Elsner P, Thiele JJ. Role of oxidative stress and the antioxidant network in cutaneous carcinogenesis. Int J Dermatol 2004;43:326-335.

50. Vostalova J, Rajnochova Svobodova A, Galandakova A, Sianska J, Dolezal D, Ulrichova J. Differential modulation of inflammatory markers in plasma and skin after single exposures to UVA or UVB radiation in vivo. Biomed Pap Med Fac Univ Palacky Olomouc Czech Repub 2013;157:137-145.

51. Girotti AW. Photosensitized oxidation of membrane lipids: reaction pathways, cytotoxic effects, and cytoprotective mechanisms. J Photochem Photobiol B 2001;63: 103-113.

52. Khanapure SP, Garvey DS, Janero DR, Letts LG. Eicosanoids in inflammation: biosynthesis, pharmacology, and therapeutic frontiers. Curr Top Med Chem 2007;7:311-340. 
53. Wang D, Dubois RN. Eicosanoids and cancer. Nat Rev Cancer 2010;10:181-193.

54. Fleming I. The cytochrome P450 pathway in angiogenesis and endothelial cell biology. Cancer Metastasis Rev 2011;30:541-555.

55. Simopoulos AP. The importance of the omega-6/ omega-3 fatty acid ratio in cardiovascular disease and other chronic diseases. Exp Biol Med (Maywood) 2008;233:674-688.

56. Gobbetti T, Le Faouder P, Bertrand J, Dubourdeau M, Barocelli E, Cenac N, Vergnolle N. Polyunsaturated fatty acid metabolism signature in ischemia differs from reperfusion in mouse intestine. PLoS One 2013; 8:e75581.

57. Scott G, Leopardi S, Printup S, Malhi N, Seiberg M, Lapoint R. Proteinase-activated receptor-2 stimulates prostaglandin production in keratinocytes: analysis of prostaglandin receptors on human melanocytes and effects of PGE2 and PGF2alpha on melanocyte dendricity. J Invest Dermatol 2004;122: 1214-1224.

58. Miller CC, Tang W, Ziboh VA, Fletcher MP. Dietary supplementation with ethyl ester concentrates of fish oil $(n-3)$ and borage oil ( $n-6)$ polyunsaturated fatty acids induces epidermal gereation of local putative antiinflammorty metabolites. J Invest Dermatol 1991; 96:98-103.

59. Cole C, Appa Y, Ou-Yang H. A broad spectrum highSPF photostable sunscreen with a high UVA-PF can protect against cellular damage at high UV exposure doses. Photodermatol Photoimmunol Photomed 2014;30:212-219. 